\title{
数値流体解析による橋梁断面の空気力評価と振動予測 Aerodynamic force and vibration prediction of cross section bridge using CFD
}

\author{
平野廣和* \\ Hirokazu HIRANO
}

\section{1. はじめに}

風工学の分野, とりわけ土木構造物の分野での数值 流体解析(CFD : Computational Fluid Dynamics)への取り 組みは，1986年に土木学会構造工学委員会「耐風設計 研究小委員会」の下部組織に「而風工学数值実験分科 会（主査：岡島厚金沢大教授(当時))」 ${ }^{1)}$ が発足し，組 織的な調査・活動を開始したことからによる、続いて 1990年に土木学会構造工学委員会に「風工学における 数值計算の応用と評価研究小委員会」(初代委員長 : 野 村卓史日大教授, 二代目委員長 : 著者) ${ }^{2), 3)}$ として, 2000 年から風洞実験とCFDとの相互を相補うことを目的と して，同委員会に「風工学における数值解析と風洞実 験の相互利用に関する研究小委員会」(委員長 : 白土博 通京大助教授(当時)） ${ }^{4)}$ が設置され，主として橋梁本体 あるいはその構造要素の風荷重や耐風応答, 流れの現 象や物体の空力性能の評価を実施することを目的とし て研究・開発が進められてきた. 特にこの分野では, 風洞実験が従来から中心的な役割を果たしてきた領域 であるので, いわゆる「数值風洞」を目指してきたこ とになり，以来33年余りの歴史の中で着実に成果を挙 げるに至っている。この結果, 静的な空気力のみなら ず, 大規模な3次元数值流体解析により振動構造物に作 用する空気力（以下，非定常空気力とする）までも解 析することが試みられ，フラッターなどの空力不安定 現象の評価等の重要な検討にも使われるようになって 来た。このため現在ではCFDが，風洞実験から全面的 に置き換わることはないまでも, 風洞実験のある部分 を置き換え，また風洞実験を相補う形で利用される様 になってきていると言っても過言ではない.
ところで, 最近の話題として建設コスト削減という 社会的な要請が求められている.この中で, 橋梁構造 物でも製作の省力化を考慮した合理化形式が増加して いる，その結果として今までは，耐風性検討の必要が 無いと考えられてきた橋梁形式においても而風性検討 が必要となって来た。机上での耐風性の検討のみなら ずの風洞実験も行なわれ，これにより耐風設計上の新 たな見地が得られるようになってきている，また，橋 梁構造物自身の耐風安定性のみならず, 利用者や風環 境に及ぼす風の影響もこれからの設計には必要不可欠 な要素となっている.このようなことから，橋梁構造 物の耐風安定性の必要性は, 今後も形を変えながらも 続いて行くだろう。

一方, 耐風安定性を必要とする設計が多様化する中 で，さらなるコスト削減は至上命題であり，風洞実験 と比較してのコストパフォーマンスに優れた耐風安定 性の検討手段としてCFDへの期待が高まっている.こ の背景には，ハードウェア環境からは計算コストの大 幅な低価格化, 特に計算機性能の大幅な向上が挙げら れる. 現在では20世紀末の超大型スーパーコンピュー タと同等あるいはそれ以上の能力を有するコンピュー タが，十数万円程度で手に入る時代となっている.さ らにソフトウェアの面では, 各種の流体汎用解析ソフ ト（商用コード）の充実が挙げられる. さらに, Open $\mathrm{FOAM}^{5}$ に代表されるオープンソースプログラムで提 供されているプラットフォームの出現により, 商用の ソフトウェアに比肩するシミュレーションが可能とな っている. これにより, 数值流体解析の専門家でなく ても風工学を専門とする研究者や技術者にも広くCFD 
が受け入れられる環境が整って来ている.

これを裹付けることとして建築分野においては, 2015年に発行された建築物荷重指針占に風荷重評価へ のCFDの活用が明記されるなど，その役割は風洞実験 と同等程度まで向上しつつある7)。よって，土木分野 においてもCFDの耐風設計への活用が広がることが期 待される.このためには, 空気力や非定常空気力さら には空力振動の応答評価において, 風洞実験と同等の 精度の確保がCFDにとって必要不可欠となって来てい る.

このような背景から, CFDが橋梁構造物の而風設計 実務に広く取り入れられるためには, 高い精度で橋梁 断面に作用寸る空気力特性が容易に解析可能な数值解 析手法を示していくことが必要である.よって本報で は, 出野ら ${ }^{8)}$ が中央径間 $2000 \mathrm{~m}$ を超える超長大橋を想定 した二箱桁断面を対象として行った風洞実験と同様の 断面形状を取り上げ, 高欄や検査車レールなどの付加 物の設置位置ならびに形状の違いによる耐風安定性の 変化を検討し, 数值流体解析による橋梁断面の空気力 評価と振動予測に関して説明するものである.

\section{2. 空気力の評価}

橋梁断面を対象とした空気力の評価に関しては，比 較する風洞実験が部分模型を用いた2次元断面である ことが多いので, 2次元解析が中心になって行われてき た．その背景には簡単に計算ができるだけではなく, 当時の計算機の能力不足もあったことも否定できない. しかし，2次元解析は文献9), 10)にも示されている通り， 時間平均的には流れの2次元性が保たれていても, 時々 刻々と変化する流れの成分が3次元性を示しているの で，橋軸方向（スパン方向）のエネルギー散逸が考慮 されていない. そのため剥離渦が強めに評価され, 剥 離流の再付着点がずれることが生ずる. その結果, 空 気力が過大または過小に評価されることから, 2次元解 析では風洞実験結果を再現するには至っていない.

この問題を解決する一つの手法として, 黒田 ${ }^{11}$ や嶋 田ら ${ }^{12,13)}$ は, RANS(Reynolds Averaged Navier-Stokes)モ デル手法を使い, 2次元解析で非定常空気力を算出する ことを行っている.しかしこれらの研究は, 後流に比 較的大きな渦であるカルマン渦列が形成される Bluff な断面を対象としており, 断面辺長比 $\mathrm{B} / \mathrm{D}=2$ 程度の矩 形断面には適用可能である. しかし, 橋梁断面の様に 前縁や後縁での剥離や小さな渦が而風安定性に影響を
与える問題では, 高風速側で風洞実験值との差が大き くなるなどの傾向が見られるため, 適用が難しくなる と考える.よって, RANSによる橋梁桁断面の空気力 評価と振動予測評価の精度は未だ解決すべき課題を有 している.

解析精度向上のためには, RANS と比較して非定常 な細かな渦まで再現可能なLES (Large Eddy Simulation) の活用がなされている. 著者らの研究グループ14)では, LESを用いて平板翼の非定常空気力係数を算出し, Theodorsen ${ }^{15}$ による理論值と同等の結果が得られるこ とを示している．また，石原ら ${ }^{16)}$ はLESを橋梁桁断面 に適用し, 非定常空気力係数が扁平矩形断面に近い性 質を示すことを示している. 最近の研究として伊藤ら ${ }^{177}$ は, 長大橋梁の而風設計におけるCFD活用のため, 高欄等の付属物が無い状態での箱桁橋梁断面の非定常 空気力係数に関し, 風洞試験との同等の精度を示して いる. 併せてスパン方向の解析領域の検討も行ってい る.

よって，信頼性ならびに詳細な精度の評価がこれか らのCFD課題となっている. ここで, 橋梁断面を扱う 解析における目標は, まず色々な迎角（風の傾斜角） で静的空気力とストローハル数が正しく求めることが できることである。これは, 流れが断面の偶角部から 剥離して断面上に再付着寸る一連の現象を正確に捉え ることができることを意味している．さらに，静的な 空気力と流れの場を正確に求めることができるならば, 断面を強制加振した時に求められる非定常空気力も正 しく求めることができるとの概念の上に立脚している. このような背景から, 著者らの研究グループ10),18)で は, 乱流モデルとして基礎方程式にLESにおけるSGS (Smagorinsky Sub-grid Scale)モデルによる空間的な Filtering操作を施した非圧縮粘性3次元Navier-Stokes方 程式を採用し，有限要素法にて解析を行っている.

\section{3. 付加物を有する二箱桁断面橋梁空気力}

\section{1 断面の特徴}

超長大橋の検討において, 経済性・耐風性に優れる 桁断面として矩形断面を並列させ，両端にフェアリン グあるいは開口部にセンターバリアを付加した二箱桁 断面が提案されている. また，長大・超長大橋の耐風 安定性断面の開発には, フラッター性能の向上が必要 不可欠な課題である. フラッターとは, 発散型現象で あり直接構造物の破壊につながる現象である。これま 
で，橋梁断面の形状や付加物の決定には，風洞実験や 数值流体解析(CFD)による検討が行われており, 一箱 桁橋の静的空気力係数や非定常空気力係数は, 概社実 験值と整合した CFD 結果が報告されている 17), 19)。し かし，二箱析断面においては，流れの干渉により複雑 な流れ場となることから, 風洞実験結果と CFD が一 致しない場合が報告されている.このため, 空力特性 に与える影響に関しては, 十分な検討と現象の解明が 必要であると指摘されている ${ }^{10)}$.

そこで，本報では高欄や検査車レールなどを付加し た実橋梁に近いモデルにおいて 3 次元数值流体解析を 行う. 具体的には, まず静的空気力を求めることで付 加物の違いによる流れ場を把握する. 次に静的空気力 の結果を用いて非定常空気力解析, フラッター解析を 行うことで振動の発生原因の特定や耐風性能の向上要 因を明らかにするとともに, 二箱桁断面橋梁でのフラ ッター発現風速を予測することを述べるものである.

\section{2 フェアリング・センターバリア付き二箱析断面}

図-1 に本報で用いる 5 種類の断面と高欄の形状を示 寸. 各断面は, $\mathrm{B} / \mathrm{D}=4$ (B:栴幅， $\mathrm{D}$ 桁高）と開口部幅 $4 \mathrm{D}$ を組合せた箱桁断面にフェアリング, センターバ リアを付加した断面である. これを基本断面とする. 断面(1)は基本断面に加えて検查車レールを断面外側か ら 1D の位置に設置, 高欄 a を外側に付加した断面で ある. 断面(2)は検查車レールを断面外側から $2 \mathrm{D}$ の位 置に設置, 高闌 $\mathrm{a}$ を外側に付加した断面である. 断面 (3)は検査車レールを断面外側から 3D の位置に設置, 高欄 a を外側付加した断面である. 断面(4)は検査車レ ールを断面(1)と同様に断面外側から 1D の位置に設置, 高欄 $\mathrm{b}$ を外側に設置した断面である. 断面(5)断面(4) に加えて, 高欄 $\mathrm{b}$ を断面の内側と外側に設置した断面 である。

\section{3 高欄・検查車レール等の付加物のモデル化}

橋梁断面への付加物の一つである高欄のモデル化に は, 出野ら ${ }^{8)}$ の風洞実験を参考とする. 図-1 に示すよ うに高闌の高さは共に $0.38 \mathrm{D}$ とし, 高欄 $\mathrm{a}$ は上下方向 に 3 本の矩形柱で構成, 高欄 $\mathrm{b}$ は上下方向に 2 本の矩 形柱で構成する.ここでの高欄の充実率は高欄 $\mathrm{a}$ を $58 \%$ ，高欄b を $53 \%$ 程度確保するように組み合わせて 再現している.また, 高欄の形状によって断面上面で の剥離点の位置が変化しないように, 設置位置および

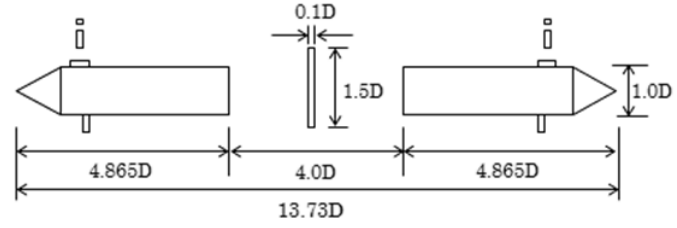

断面(1)（高欄 $\mathrm{a}$, 検查車レール 1D)

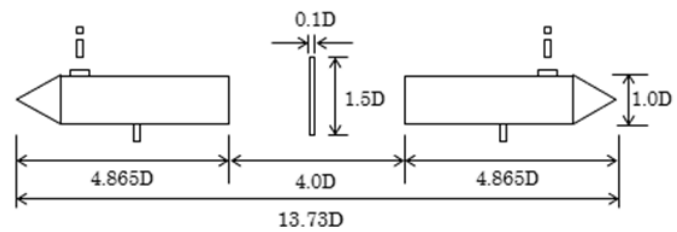

断面(2)（高欄 a，検査車レール 2D）

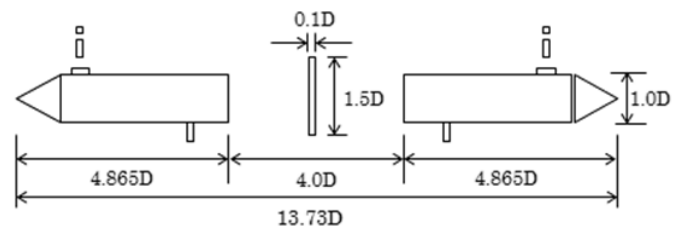

断面(3)（高欄 a ，検査車レール 3D）

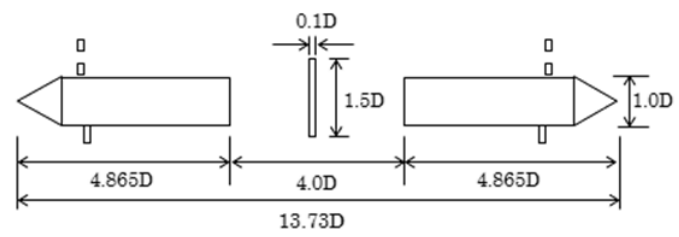

断面(4)（高欄 $\mathrm{b}$, 検査車レール 1D)

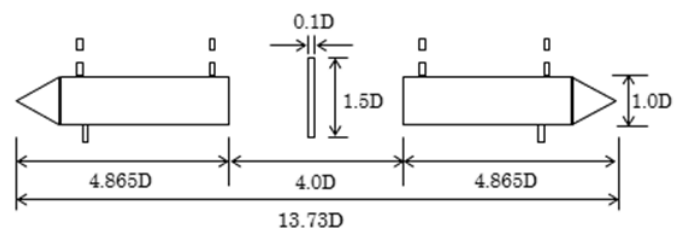

断面(5)（高欄 b 2 カ所，検査車レール 1D）
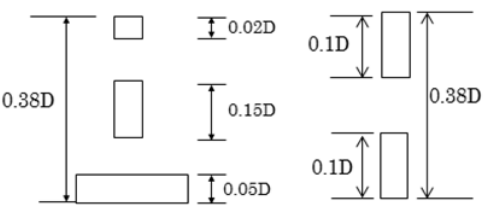

高欄 a (充実率 $58 \%$ )

高欄 b (充実率 53\%)

図-1 フェアリング・センターバリア付き

二箱桁断面橋梁と高欄

高欄頂点の形状に注意してモデル化を行っている．な お，高欄や検查車レールで流れの剥離を正確に再現す るために, 剥離点近傍での最小要素幅は $0.0005 \mathrm{D}$ とし, 断面近傍に近づくほど細かくなるように設定している. 
これにより，高欄の形状及び充実率によって断面の空 力特性が変化することも同時に確認する．検查車レー ルの寸法に関しても前述の風洞実験 8) と同様の矩形柱 でモデル化を行なう.

\section{4 解析条件}

表-1 に解析諸元, 図-2 に解析領域と図-3 に断面(1) 周辺の詳細の要素分割図をそれぞれ示す.境界条件は, $\Gamma_{1}$ で無次元流速である一様流速 $1.0, \quad \Gamma_{2}$ では移流境 界条件とする. また， $\Gamma_{3}$ で slip, $\Gamma_{4}$ で no-slip 条件 とし，断面軸方向の境界 $\Gamma_{5}$ では周期境界条件を用い ている. 解析領域は奥行き方向の軸方向長さを $3.2 \mathrm{D}$ とし, 軸方向分割を 32 として軸方向幅を $0.1 \mathrm{D}$ として いる．迎角は，頭上げをプラス方向とし， $\alpha=0.0^{\circ}$ を 中心に $-8.0^{\circ} \sim+8.0^{\circ}$ の間を迎角 $1.0^{\circ}$ ピッチで行う. なお，軸方向の分割に関しては，著者らの研究グルー プの解析実績 10), 14)から必要最小限の領域を確保して いる.

\section{5 静的空気力}

図-4に各断面の静的空気力係数を示す. 図-4(a)の抗 力係数 $\left(\mathrm{C}_{\mathrm{d}}\right)$ に着目寸ると断面(2), (3)は断面(1)に比べ て迎角変化に伴う抗力係数が低く抑えている．ここか ら，検查車レールが断面の内側にある方が抗力低減効 果のある断面であるとわかる，さらに，図-4(b)の揚力 係数 $\left(\mathrm{C}_{1}\right)$ に着目すると, 全断面において迎角変化に 伴う勾配が正勾配であることから，たわみ振動現象発 生の可能性は低いと考えられる. 一方, 図-4(c)のピッ チングモーメント係数 $\left(\mathrm{C}_{\mathrm{m}}\right)$ に着目すると, 断面(1)は 迎角 $\alpha=5^{\circ} \sim 6^{\circ}$ で迎角変化に伴う勾配が正勾配から 負勾配に変化しているこのことから，検查車レールを 外側に設置した断面では，高迎角時でねじれ振動現象 発生の可能性が考えられる.

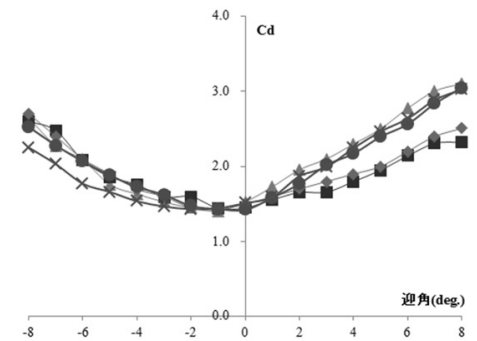

(a) 抗力係数 $\left(\mathrm{C}_{\mathrm{d}}\right)$

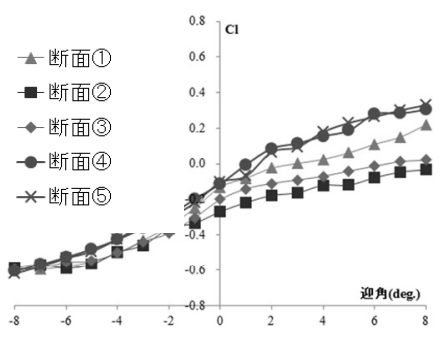

(b) 揚力係数 $\left(\mathrm{C}_{1}\right)$
表-1 二箱析断面の解析諸元

\begin{tabular}{|c|c|c|c|c|c|}
\hline 断面形状 & 断面(1) & 断面(2) & 断面(3) & 断面(4) & 断面(5) \\
\hline 時間増分 $\Delta \mathrm{t}$ & $0.02 \mathrm{D} / \mathrm{U}$ & $0.02 \mathrm{D} / \mathrm{U}$ & $0.02 \mathrm{D} / \mathrm{U}$ & $0.02 \mathrm{D} / \mathrm{U}$ & $0.02 \mathrm{D} / \mathrm{U}$ \\
\hline 最小要素幅 & $0.0005 \mathrm{D}$ & $0.0005 \mathrm{D}$ & $0.0005 \mathrm{D}$ & $0.0005 \mathrm{D}$ & $0.0005 \mathrm{D}$ \\
\hline 総接点数 & $32330 \times 33$ & $30722 \times 33$ & $32330 \times 33$ & $48661 \times 33$ & $58709 \times 33$ \\
\hline 総要素数 & $31752 \times 32$ & $30168 \times 32$ & $31752 \times 32$ & $48000 \times 32$ & $57900 \times 32$ \\
\hline Reynolds数 $\mathrm{Re}$ & \multicolumn{5}{|c|}{$3.0 \times 10^{4}$} \\
\hline 軸方向長さ & \multicolumn{5}{|c|}{$3.2 \mathrm{D}$} \\
\hline 軸方向分割 & \multicolumn{5}{|c|}{32} \\
\hline 軸方向幅 & \multicolumn{5}{|c|}{$0.1 \mathrm{D}$} \\
\hline モデル定数 Cs & \multicolumn{5}{|c|}{0.1} \\
\hline
\end{tabular}

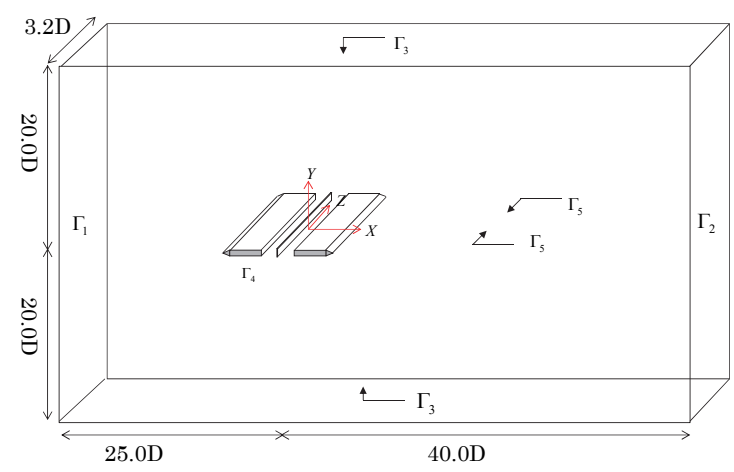

図-2 解析領域

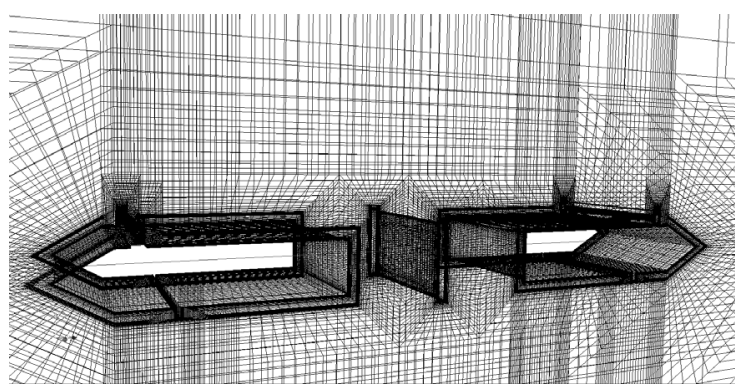

図-3 断面(1)詳細要素分割図

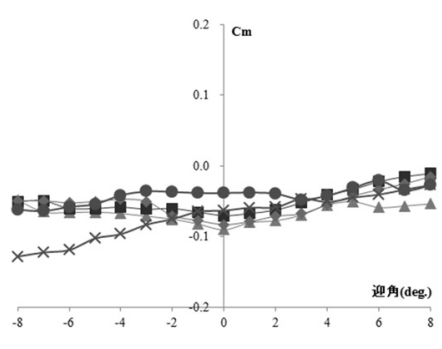

(c) ピッチングモーメント係数 $\left(\mathrm{C}_{\mathrm{m}}\right)$

図-4 空気力係数 
ほぼ同様である．図-4(c)のピッチングモーメント係数 では，断面(4)，(5)ともに迎角変化に伴う勾配が断面(1) に比べて低く抑えられていることが確認できることか ら，高欄の開口率を上げたことでねじれ振動現象発生 を抑制していると考えられる．また，高欄を断面内側 に設置した断面(5)，断面(1)，(4)と比べて迎角変化に 伴う勾配が低く抑えられている，このことから，高欄 を断面内側に付加することで, 開口部に入り込む風を 抑制していると考えられ，それがピッチングモーメン 卜抑制に作用したと思われる. 次に断面(4), (5)の迎角 $\alpha=5^{\circ} \sim 6^{\circ}$ に着目寸ると, 断面(1)で見られた負勾配 は確認されなかった。しかしながら, 断面(4), 断面(5) においても負勾配を示している点があることから，検 查車レールを外側に付加した断面では迎角が変わるこ とで流れの特性が変化する点が存在すると考えられる.

\section{4. 付加物を有する二箱桁断面橋梁のフラッター特性}

\section{1 振動構造物に作用寸る空気力}

静的空気力結果から正確な流れ場を再現できたと考 えられる，そこで振動状態に関する流れ場を把握する ために, 1 自由度たわみ・ねじれ強制加振動的解析を 行う。ここで強制加振は, たわみ片振幅 $\eta_{0}=0.1 \mathrm{D}$, ね じれ片振幅 $\phi_{0}=1.0^{\circ}$ とし, 風洞実験值 ${ }^{8)}$ と同様の值に 設定する.

たわみ・ねじれ振幅の振動時における非定常揚力 $L$ と非定常空力モーメント $M$ は, 8 個の非定常空気力係 数を用いて式(1),(2)のように表される.

$$
\begin{aligned}
& m\left(\ddot{\eta}+2 \xi_{\eta 0} \omega_{\eta 0} \dot{\eta}+\omega_{\eta 0}{ }^{2} \eta\right)=L= \\
& \pi \rho B^{2} \omega^{2}\left(C_{L \eta R} \eta+C_{L \eta I} \frac{\dot{\eta}}{\omega}+C_{L \theta R} B \phi+C_{L \theta I} \frac{B \dot{\phi}}{\omega}\right) \\
& I\left(\ddot{\phi}+2 \xi_{\phi 0} \omega_{\phi 0} \dot{\phi}+\omega_{\phi 0}{ }^{2} \phi\right)=M= \\
& \pi \rho B^{3} \omega^{2}\left(C_{M \eta R} \eta+C_{M \eta I} \frac{\dot{\eta}}{\omega}+C_{M \theta R} B \phi+C_{M \theta I} \frac{B \dot{\phi}}{\omega}\right)
\end{aligned}
$$

$L:$ 非定常揚力, $M$ : 非定常空力モーメント $\eta:$ 鉛直変位, $\phi:$ ねじれ変位, $\omega:$ 円振動数

一般的に非定常空気力係数のうち, $\mathrm{C}_{\mathrm{M}_{\eta}} \mathrm{I}, \mathrm{C}_{\mathrm{L}_{\theta} \mathrm{R}}$ は值 が小さければ小さいほど, また特に $\mathrm{C}_{\mathrm{M}_{\theta} \mathrm{I}}$ は負で絶対 值が大きいほどフラッターに安定的と言われている. さらに $\mathrm{C}_{\mathrm{M}_{\theta} \mathrm{R}}$ は值が小さいほど, 連成フラッターに対 し安定性を向上させると言われている.
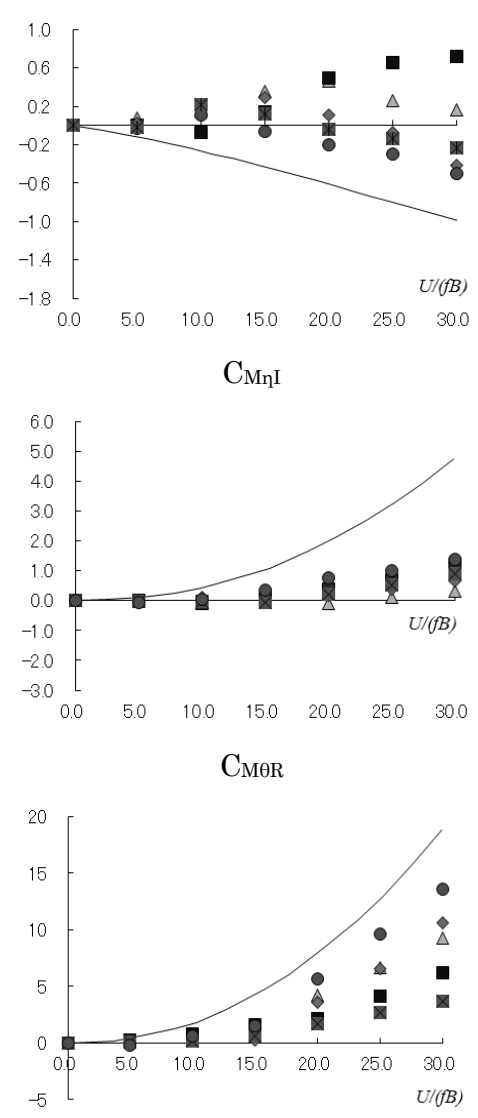

$\mathrm{C}_{\mathrm{L} \theta \mathrm{R}}$

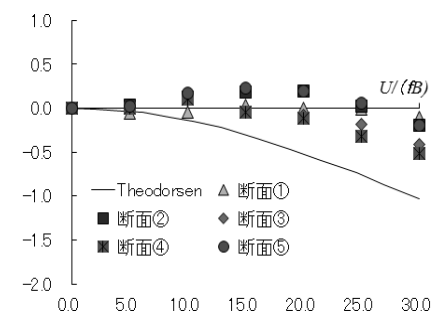

СмөІ

図-5 非定常空気力係数

図-5に非定常空気力係数のうち, 上記に示した係数 の結果を示す. 各係数を比較すると無次元風速 $U /(f B)=15.0$ 以上でそれぞれの断面特性が異なってい る.これは高風速時においては高欄や検查車レールの 付加物の設置位置により流れの状態が変化することを 表している.

たわみ振動解析結果である $\mathrm{C}_{\mathrm{M}_{\eta} \mathrm{I}}$ では, 断面(1), (2) において $U /(f B)=15.0$ を超える付近で正の勾配を示 しており，断面(3)と特性が異なっている。ここから検 


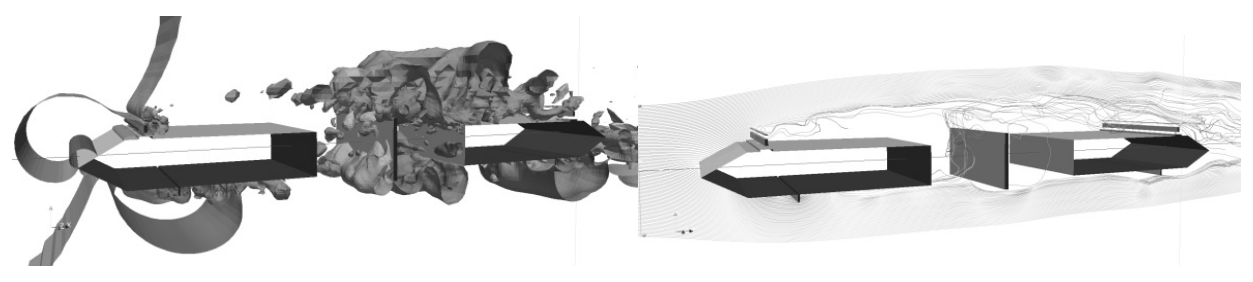

断面(1)

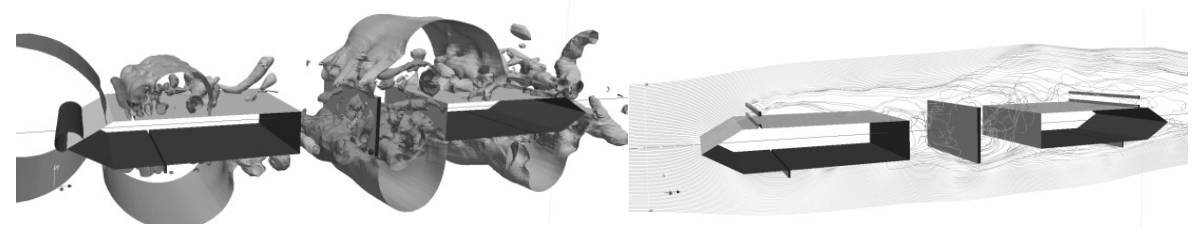

断面(4)

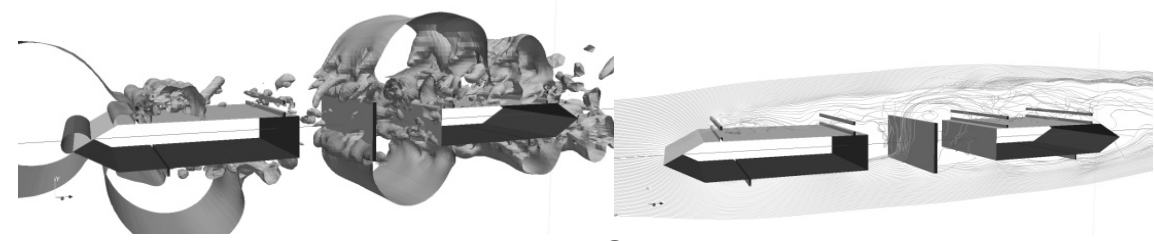

断面(5)

瞬間圧力分布図

瞬間流線図

図-6 強制加振時の流れ場(たわみ加振 $U /(f B)=15.0)$

査車レールを内側に付加することでたわみ振動に関し て安定すると考えられる. 次に, ねじれ振動解析結果 である $C_{L \theta R}, C_{M \theta R}, C_{M \theta I}$ では，各断面において理論值 とほぼ同様の傾向を示している。その中で高欄の形状 が異なる断面(4)では，他の断面に比べて $C_{M \theta I}$ は負で絶 対值が大きく, $C_{M \theta R}$ は值が小さい值を示している．こ こから高欄の形状を変化させることでフラッターに対 し影響がでると考えられる.

次に図-6に流れ場の状態の状態として, 非定常空気 力係数に変化が表れ始める $U /(f B)=15.0$ 時の瞬間圧 力分布と瞬間流線図を示す。まず，瞬間圧力分布図に 着目すると，高欄の形状が異なる断面(4)，断面(5)では 断面近傍の圧力が高くなっている.これは高欄 $\mathrm{b}$ では 剥離した流れが断面に再付着していることから圧力が 上がったと思われる。瞬間流線図に着目すると，セン ターバリアの存在により下流断面の再付着位置が断面 側面となっており，その後検査車レール付近で再剥離 している様子が確認できる。また，断面(1)と断面(5)で は開口部に gap flow の存在が確認できる. 一方, 断面 (4)では断面上面からの風と下面からの風が相殺し, 開 口部に入り込む風を抑制していると考えられ，それが 非定常空気力の低減に作用したと思われる.
4.2 フラッター解析

前節で求めた非定常空気力係数を用いてたわみ・放 じれ 2 自由度フラッター解析を行う. その際の構造諸 元を表-2 に示す。この条件は，東京湾横断道路を想定 した支間 $2,800 \mathrm{~m}$ の吊橋における鉛直曲げ，ねじれの 各 1 次モードの諸元 ${ }^{8)}$ を基にしたものである.

図-7, 図-8 に風速 U と, 算出されたたわみ・ねじ れ両空力減衰率 $\delta$ の関係を示す. これによると図-7 の たわみ減衰率は全ての断面において常に正の值を示し ている.このことからギャロッピング現象のような鉛 直曲げの発散振動は発生しないと考えられる. 一方, 図-8の放じれ減衰率は正から負へと移行している。こ の時の風速でねじれフラッターの発現が危惧されるた め, 本解析断面ではねじれフラッターのみが問題とな ることが判る。

次に, 表-3に断面形状の違いによるフラッター発現 風速を示す. 各断面を比較すると，断面(1)を除く全て の断面が Theodorsen 理論よりも高い結果となり，開 口部を有する橋梁断面の耐風性の高さがうかがえる. 特に，断面(2)と断面(3)のフラッター発現風速は断面(1) と比較して約 1.5 倍程度大きく, 検査車レールを内側 に設置することで高い耐風安定性を有することが確認 
できる，図-5に着目すると，最もねじれフラッターへ 影響を及ぼすとされている $\mathrm{C}_{\mathrm{M}_{\theta} \mathrm{I}}$ はこの領域であまり 差が出ていない.一方, 連成項である $\mathrm{C}_{\mathrm{M}_{\eta} \mathrm{I}}$ と $\mathrm{C}_{\mathrm{L}_{\theta} \mathrm{R}}$ に おいて $U /(f B)=15.0 \sim 25.0$ 付近で各断面に顕著な差が みられる。このことから， $\mathrm{C}_{\mathrm{M}_{\eta} \mathrm{I}}, \mathrm{C}_{\mathrm{L}_{\theta} \mathrm{R}}, \mathrm{C}_{\mathrm{M}_{\theta} \mathrm{I}}, \mathrm{C}_{\mathrm{M}_{\theta} \mathrm{I}}$ が複合的に影響して耐フラッター性能を決定するのに 対し, $\mathrm{CM}_{\eta} \mathrm{I}$ と $\mathrm{C}_{\mathrm{L}_{\theta} \mathrm{R}}$ がフラッター性能には大きく影響 していると推察できる.

以上，本報では，代表流速 $U$ 一定として振動数 $f$ を 調整することで無次元風速を算出する手法を採用して きた. このため, 高風速側になると加振振動数が小さ くなることから，計算を開始してから流れ場が安定す るまでの繰り返し計算数が増加する. そのため高風速 側になるにつれて計算時間が増大寸ることになる．ま た，同時に物体の動きがゆっくりとなることから静的 な状態で求めた空気力の影響が解析上，顕著に現れる と推測される.また，フラッターは静的な時間的な組 み合わせであるため, 静的空気力を正確に求めること が必要条件になる。

\section{5. おわりに}

本報では，橋梁構造物に作用する空気力評価と振動 予測に関して, 超長大橋を想定した二箱析断面に高欄 や検查車レールなどの付加物を付加し, その設置位置 ならびに形状の違いによる耐風安定性の変化を LES による 3 次数值流体解析で検討することを説明してき た.ここでは，風洞実験という制御された流れを対象 としてできる限り同一条件の基に解析を行ってきたが, 実験結果と同一の結果を再現することはなかなか難し いものであった.これには, 計算条件のわずかな差異,

例えば軸方向の分割などや解析法の差異が如実に解析 結果に反映してきて結果がばらつくなど, 非線形解析 を行う時の宿命とも言える。しかしながら，現状では 風洞実験の再現性を考えた場合, LES による 3 次元解 析手法が最も優れた手法の一つであると判断する.

一方, 風洞実験においても実際の構造物に起こって いる現象との対比で言えば，相似則の問題や風の乱れ の問題など内在する中で, 多年にわたる実績を持って 信頼性を得てきた. 数值流体解析においてもそのよう な意味で, 設計実務に数值流体解析を試みて設計上の 判断に有効な検知を積み重ね, 実務に役立つという意 味での予測可能な範囲を拡大することが望まれる。こ れが, 数值流体解析の真の実用化のために大事である
表-2 構造諸元

\begin{tabular}{|c|c|}
\hline 桁幅 $B$ & $36[\mathrm{~m}]$ \\
\hline 単位長さ重量 $m$ & $3000\left[\mathrm{~kg} f / \mathrm{s}^{\wedge} / \mathrm{m}^{\wedge} 2\right]$ \\
\hline 単位長さ極慣性 $I$ & $402100\left[\mathrm{kgf} / \mathrm{s}^{\wedge} 2\right]$ \\
\hline 鉛直たわみ振動数 $f n \eta$ & $0.062[\mathrm{~Hz}]$ \\
\hline ねじれ振動数 $f n \varphi$ & $0.126[\mathrm{~Hz}]$ \\
\hline たわみ構造減衰率 $\delta \eta 0$ & 0.02 \\
\hline ねじれ構造減衰率 $\delta \varphi 0$ & 0.02 \\
\hline
\end{tabular}

表-3 フラッター発現風速

\begin{tabular}{|c|c|}
\hline & フラッター発現風速 $U c r$ \\
\hline 断面(1) & $40 \mathrm{~m} / \mathrm{s}$ \\
\hline 断面(2) & $61.1 \mathrm{~m} / \mathrm{s}$ \\
\hline 断面(3) & $62.4 \mathrm{~m} / \mathrm{s}$ \\
\hline 断面(4) & $51 \mathrm{~m} / \mathrm{s}$ \\
\hline 断面(5) & $45 \mathrm{~m} / \mathrm{s}$ \\
\hline Theodorsen & $41.0 \mathrm{~m} / \mathrm{s}$ \\
\hline
\end{tabular}

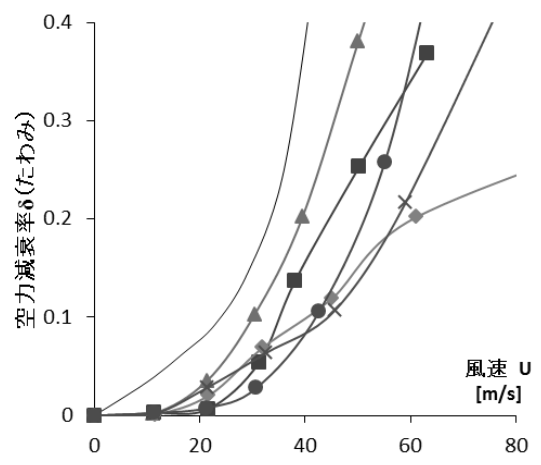

図-7 たわみ空力減衰率

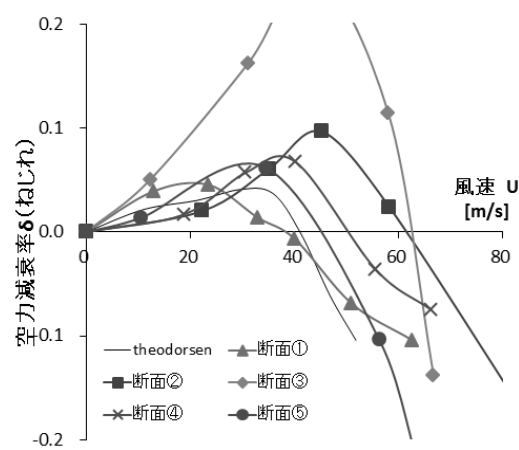

図-8 ねじれ空力減衰率

と考えている.

ここで取り上げた断面や付加物が，円柱断面や隅角 部に曲線を有する矩形断面など形状が単純なもの程, この難しさの傾向はさらに強くなる可能性が高い．例 えば円柱断面での臨界レイノルズ数付近における流れ の不安定さであるドラッグクライシス (Drag Crisis) 
を捕らえる解析 18),20)が，研究段階の域を未だに出てい ないことなどである，特に，商用コード等を使う場合 等, この問題は既に解決済みであると誤って解釈して いる研究者もいることを注意するべきである.

以上のように, 数值流体解析で橋梁構造物に作用寸 る空気力評価と振動予測を行う場合には, 静的な状態 での橋梁断面に作用する空気力を正確に求めることが 必要条件である.さらに，これを満た寸ための格子生 成やメッシュ分割等のモデル化, 軸方向長さや分割, 境界条件等の解析条件の設定等々, 計算コストとの兼 放合いでの検討をしなくてはならないことが残されて いる. ただし, 数值流体解析を行うハードウェアは, これからも大幅な性能向上と低価格下が望める状況な ので, ソフトウェア上の検討項目をハードウェアの進 歩が網羅する可能性もある.このようになれば, 数值 流体解析（CFD）による風工学への寄与はさらに大き くなると思われる.

最後に，ここで取り上げた二箱桁断面の空気力の解 析は, 川﨑貴之 (東海旅客鉄道(株) , 栗林伶二 (首都高 速道路(侏) の中央大学大学院理工学研究科土木工学専 攻での修士論文の研究の一環として行われたものであ ることを付記する。

\section{参考文献}

1）耐風工学のための数値風洞実験に関する文献集, 土木学 会耐風設計研究小委員会耐風工学数值実験分科会, 1989.3.

2) 風工学における数值計算の応用と評価研究小委員会報 告書, 土木学会構造工学委員会, 1993.

3) 風工学における数值計算の応用之評価研究小委員会報 告書成果報告会資料集, 土木学会構造工学委員会, 1999.

4）風工学における数值解析と風洞実験の相互利用に関す る研究小委員会報告書, 土木学会構造工学委員会, 2004.

5) Open FOAM:https://openfoam.org/maintenance/

6) 日本建築学会(編) : 建築物荷重指針・同解説〈2015〉, 日本建築学会, 2015 .

7）岸田岳士，田村哲郎，野津剛，勝村章，奥田泰雄，溜正 俊: LES による建築物の風荷重評価の実用化検討, 風工 学シンポジウム論文集, Vol.22, pp.293-298, 2012.

8）出野真由子, 吉住文太, 兽我明, 井上浩男:付加物を有 する二箱桁断面における耐風安定性の検討, 構造工学論 文集, Vol. 53A. pp. 634-641. 2007.
9) 平野廣和, 渡邊茂, 丸岡晃, 佐野健一: 3 次元数值流体 解析における軸方向長さの検討一断面辺長比 4 の矩形断 面の場合一, 土木学会論文集 No.647/I-51, pp.447-452, 2000.

10) 川㠃貴之, 樽川智一, 佐藤亮, 平野廣和, 佐藤尚次 : 数 值流体解析による二箱析断面橋梁の耐風安定性の検討, 土木学会応用力学論文集 Vol.11, pp.761-768, 2008.

11）黒田眞一: 2 方程式乱流モデルを用いた長大橋非定常空 気力の数值計算, 土木学会論文集 No.654/I-52, pp.377387,2000 .

12）嶋田健司, 石原孟 : $K-\varepsilon$ モデルによる扁平断面の非定常 空気力予測, 計算工学論文集, Vol.6, No.1, pp.285-288, 2001.

13) 嶋田健司, 石原孟, 若原敏裕 : $K-\varepsilon$ モデルによる矩形断 面柱のフラッター解析, 第 17 回風工学シンポジウム, pp.291-296, 2002.

14）丸岡晃, 平野廣和 : 数值流体解析による非定常空気力の 算出について, 応用力学論文集, Vol.3, pp.707-712, 2000.

15) Theodorsen, T.: General Theory of Aerodynamic Instability and the Mechanism of Flutter,Technical report, US National Advisory Committee for Aeronautics, 1935.

16）石原孟, 嶋田健司, 山崎康嗣, 池田虎彦: 3 次元数值流体 解析による斜張橋主桁断面の空力性能の予測, 構造工 学論文集, Vol.52A, pp.611-620, 2006.

17）伊藤靖晃, J. Michael R. Graham：LES による箱析橋 梁断面の空気力評価とスパン方向解析領域の影響の検 討, 土木学会論文集 A1 (構造・地震工学), Vol.73, No.1, pp.218-231, 2017.

18）糟谷直樹, 平野廣和, 丸岡晃, 佐藤尚次 : 数值流体解析 を用いた臨界領域における円柱まわりの流れの特徴の 把握, 土木学会構造工学論文集, Vol.60A, pp.410-417, 2014.3.

19）渡邊茂，丸岡晃，井上浩男：フェアリングを有する箱 桁断面に作用する静的空気力の数值流体解析による検 討, 第 17 回風工学シンポジウム論文集, pp.219-224, 2002.12 .

20）小野佳之, 田村哲郎：臨界レイノルズ数域における円柱 まわりの非対称流れに関する LES, 第 23 回風工学シン ポジウム論文集, pp199-204, 2014.12. 